\title{
PENGARUH EARNING PER SHARE DAN PRICE EARNING RATIO TERHADAP DEBT TO EQUITY RATIO DAN HARGA SAHAM PADA PERUSAHAAN SEKTOR MAKANAN DAN MINUMAN DI BURSA EFEK INDONESIA
}

\begin{abstract}
The purpose of this study was to determine whether there is influence: 1) earning per share of the debt to equity ratio; 2) price earnings ratio of the debt to equity ratio; 3) earnings per share to the stock price; 4) price earnings ratio of the stock price; 5) debt to equity ratio to stock prices; 6) earnings per share to share prices through debt to equity ratio; 7) price earnings ratio of the stock price through a debt to equity ratio. The study design used is quantitative descriptive. Secondary data types, method of data collection through the documentation. The population used in this study is the enterprise data food and beverage sector in the Indonesia Stock Exchange (BEI) as many as 17 companies. The sampling technique purposive sampling method. Analysis of data to test the hypothesis in this study using path analysis (Path analys). Based on the analysis can be concluded that: 1) there is significant negative influences of the Earning Per Share (EPS) of the Debt to Equity Ratio (DER); 2) there is no significant positive effect of price earning ratio (PER) of the Debt to Equity Ratio (DER); 3) there is a significant negative influence Earning Per Share (EPS) to share price; 4) there is a significant positive effect Price Earning Ratio (PER) on stock prices; 5) there is a significant positive effect Debt to Equity Ratio (DER) on stock prices; 6) there is indirect influence Earning Per Share (EPS) to share price through the Debt to Equity Ratio (DER) and 7) There is an indirect effect Price Earning Ratio (PER) on stock prices through the Debt to Equity Ratio (DER).
\end{abstract}

Keywords: Earning Per Share (EPS), Price Earning Ratio (PER), Debt to Equity Ratio (DER), the stock price

\section{abstrak}

Tujuan dari penelitian ini adalah untuk mengetahui apakah terdapat pengaruh : 1) earning per share terhadap debt to equity ratio; 2) price earning ratio terhadap debt to equity ratio; 3) earning per share terhadap harga saham; 4) price earning ratio terhadap harga saham; 5) debt to equity ratio terhadap harga saham; 6) earning per share terhadap harga saham melalui debt to equity ratio; 7) price earning ratio terhadap harga saham melalui debt to equity ratio. Desain penelitian yang digunakan dalam penelitian ini adalah deskriptif kuantitatif. Jenis data sekunder, metode pengumpulan data melalui dokumentasi. Populasi yang digunakan dalam penelitian ini adalah data perusahaan sektor makanan dan minuman di Bursa Efek Indonesia (BEI) sebanyak 17 perusahaan. Teknik pengambilan sampel dengan metode purposive sampling. Analisis data untuk pengujian hipotesis pada penelitian ini menggunakan analisis jalur (Path Analys). Berdasarkan analisis dan pembahasan dapat disimpulkan bahwa: 1) terdapat pengaruh negatif signifikan Earning Per Share (EPS) terhadap Debt to Equity Ratio (DER); 2)terdapat pengaruh positif tidak signifikan Price Earning Ratio (PER) terhadap Debt to Equity Ratio (DER); 3) Terdapat pengaruh negatif signifikan Earning Per Share (EPS) terhadap harga saham; 4) Terdapat pengaruh positif signifikan Price Earning Ratio (PER) terhadap harga saham; 5) Terdapat pengaruh positif signifikan Debt to Equity Ratio (DER) terhadap harga saham; 6) Terdapat pengaruh tidak langsung Earning Per Share (EPS) terhadap harga saham melalui Debt to Equity Ratio (DER) dan 7) Terdapat pengaruh tidak langsung Price Earning Ratio (PER) terhadap harga saham melalui Debt to Equity Ratio (DER).

Kata Kunci : Earning Per Share (EPS), Price Earning Ratio (PER), Debt to Equity Ratio (DER), harga saham 


\section{A. PENDAhULUAN}

Upaya untuk mendapatkan dana dengan cara paling menguntungkan serta mengalokasikan dana secara efisien dalam perusahaan sebagai sarana untuk mencapai sasaran bagi kekayaan pemegang saham (Kamaludin dan Indriani, 2012:01).

Analisis internal perusahaan dapat diukur dari laporan keuangan pada setiap periode yang berasal dari neraca dan laporan laba rugi. Analisis laporan keuangan yang dilakukan adalah menyangkut rasio-rasio keuangan perusahaan yang dapat menggambarkan kinerja perusahaan.

Rasio keuangan atau financial ratio sangat penting gunanya untuk melakukan analisa terhadap kondisi keuangan perusahaan (Fahmi, 2012:44). Laporan keuangan perusahaan yang go public dapat dilihat di Bursa Efek. Bursa efek merupakan perusahaan yang jasa utamanya menyelenggarakan kegiatan perdagangan sekuritas di pasar sekunder (Husnan, 2012:30).

Saham (stock) dapat didefinisikan sebagai tanda penyertaan atau kepemilikan seseorang atau badan dalam suatu perusahaan atau perseroan terbatas (Darmadji dan Fakhruddin, 2012:05).

Pergerakan ekonomi yang melambat ternyata berdampak terhadap industri makanan dan minuman ringan. Salah satu yang ikut merasakan dampaknya adalah PT Indofood Sukses Makmur. Presiden Direktur PT Indofood Anthoni Salim mengatakan melemahnya nilai tukar rupiah terhadap dolar Amerika Serikat ikut mempengaruhi kinerja perusahaan sepanjang kuartal pertama 2015. Sepanjang kuartal pertama ini PT Indofood hanya sanggup meraup laba sebesar Rp 870,08 miliar. Jumlah itu lebih rendah 37,2 persen dari 2014 di periode yang sama, yaitu sebesar Rp1,38 triliun. Dari laporan keuangan yang telah diumumkan laba per saham pun turun menjadi Rp 20 dari sebelumnya Rp 25. Perusahaan membagikan deviden sebanyak Rp 220 per lembar saham dalam rapat umum pemegang saham tahunan. Hal sebaliknya terjadi di anak perusahaan Indofood, yaitu PT Indofood CBP Sukses Makmur Tbk yang meraih laba bersih Rp 796,79 miliar di kuartal I ini. Jumlah ini lebih tinggi 13,8 persen dibanding tahun sebelumnya Rp 698,72 miliar (Budiman, 2015).

Menurut Husnan (2012:29), saham merupakan secarik kertas yang menunjukkan hak pemodal (yaitu pihak yang memiliki kertas tersebut) untuk memperoleh bagian dari prospek atau kekayaan organisasi yang menerbitkan sekuritas tersebut dan berbagai kondisi yang memungkinkan pemodal tersebut menjalankan haknya. Saham merupakan salah satu dari beberapa alternatif yang dapat dipilih untuk berinvestasi.

Menurut Husnan (2012:290) dasar yang dapat digunakan untuk meramalkan harga saham diantaranya yaitu laba perusahaan, pertumbuhan penjualan, dividen yang dibagikan, EPS, variabilitas laba dan sebagainya. Oleh karena itu para investor hendaknya berlaku cermat dalam menetapkan keputusannya pada pembelian salah satu saham perusahaan yang diminatinya.

EPS merupakan rasio antara pendapatan setelah pajak dengan jumlah saham yang beredar. EPS juga merupakan gambaran mengenai kemampuan perusahaan dalam menghasilkan keuntungan bersih dalam setiap lembar saham. Karena itu, EPS mempunyai pengaruh kuat terhadap harga saham dan ketika EPS meningkat maka harga saham juga ikut meningkat dan demikian pula sebaliknya.

Besarnya pengaruh yang diberikan oleh variabel EPS terhadap harga saham disebabkan para investor cenderung lebih mempercayai pertumbuhan EPS dari suatu perusahaan yang menawarkan 
saham dibandingkan dengan pertumbuhan penjualannya. Sebab mereka meyakini bahwa EPS yang tinggi menandakan bahwa perusahaan tersebut mampu memberikan tingkat kesejahteraan yang lebih baik kepada pemegang saham, sedangkan EPS yang rendah menandakan bahwa perusahaan gagal memberikan manfaat sebagaimana diharapkan oleh pemegang saham. Dengan adanya kepercayaan dari para investor terhadap salah satu saham yang ditawarkan maka akan terjadi peningkatan jumlah permintaan terhadap saham perusahaan tersebut dan dapat mendorong naiknya harga saham (Djauharotun, 2005).

Price Earning Ratio menunjukkan perbandingan harga saham yang dibeli dengan earning yang akan diperoleh dikemudian hari sehingga hal tersebut menunjukkan bahwa investor yakin terhadap besarnya earning yang diberikan perusahaan, yang nantinya akan dibagikan kepada pemegang saham dalam bentuk dividen dimasa datang. Price Earning Ratio menunjukkan pertumbuhan laba dari perusahaan, dan investor akan tertarik terhadap pertumbuhan laba tersebut sehingga pada akhirnya akan memberikan efek terhadap pergerakan harga saham. Menurut Dewi dan Sudiartha (2013) PER terhadap harga saham berpengaruh negatif. Ini berarti dikarenakan bahwa investor cenderung berinvestasi pada perusahaan yang memiliki nilai PER rendah. Investor tidak melihat harga saham sebagai acuan dalam berinvestasi, tetapi investor menggunakan tingkat laba perlembar saham oleh yang dikeluarkan oleh perusahaan. Dalam hal ini nilai PER yang rendah dapat menunjukkan bahwa tingkat laba per lembar saham yang dihasilkan oleh suatu perusahaan adalah rendah yang jika dibandingkan pada harga saham tersebut.
Menurut Mulyadi dalam Sisca (2010:9), Debt to equity ratio menggambarkan perbandingan antara total hutang dengan total ekuitas perusahaan yang digunakan sebagai sumber pendanaan usaha. Debt to equity ratio mengungkapkan bagaimana penggunaan pendanaan perusahaan dari struktur modal yang dimiliki oleh perusahaan yang berasal dari utang jangka panjang dan modal yang berasal dari ekuitas. Semakin besar DER menandakan struktur permodalan usaha lebih banyak memanfaatkan utang-utang relatif terhadap ekuitas dan mencerminkan risiko perusahaan yang relatif tinggi. Menurut Irkham, dkk (2014) DER berpengaruh signifikan positif terhadap harga saham, artinya semakin tinggi nilai DER maka akan semakin tinggi pula harga saham. Debt to equity ratio mengungkapkan bagaimana penggunaan pendanaan perusahaan dari struktur modal yang dimiliki oleh perusahaan yang berasal dari utang jangka panjang dan modal yang berasal dari ekuitas. DER berpengaruh positif terhadap harga saham menunjukkan bahwa investor memperhatikan berapa besar modal yang dibiayai oleh mereka kepada perusahaan untuk menghasilkan laba bersih untuk mereka. Semakin besar DER menandakan struktur permodalan usaha lebih banyak memanfaatkan dana yang disediakan oleh kreditur untuk menghasilkan laba.

Berdasarkan penelitian mengenai pengaruh earning per share, price earning ratio dan debt to equity ratio terhadap harga saham menunjukkan hasil yang berbeda-beda sehingga membuktikan adanya research gap, maka penelitian ini perlu untuk dikaji kembali dengan tujuan untuk memperjelas temuan selanjutnya, sehingga peneliti tertarik melakukan penelitian tentang Pengaruh Earning Per Share dan Price Earning Ratio terhadap Debt To Equity Ratio dan 
Harga Saham Pada Perusahaan Sektor Makanan dan Minuman di Bursa Efek Indonesia.

\section{B. TINJAUAN PUSTAKA Harga Saham}

Menurut Husnan (2012:29), saham merupakan secarik kertas yang menunjukkan hak pemodal (yaitu pihak yang memiliki kertas tersebut) untuk memperoleh bagian dari prospek atau kekayaan organisasi yang menerbitkan sekuritas tersebut dan berbagai kondisi yang memungkinkan pemodal tersebut menjalankan haknya. Saham merupakan salah satu dari beberapa alternatif yang dapat dipilih untuk berinvestasi.

Menurut Hery (2011:273) harga pasar saham terbentuk sebagai hasil interaksi antara pembeli dan penjual. Ketika saham dijual dengan harga di bawah nilai nominal (nilai pari), maka saham tersebut dikatakan dijual dengan diskonto (disagio).

Kismono (2011:416) menyatakan saham merupakan sebuah piagam yang berisi aspek-aspek penting bagi perusahaan, termasuk hak dari pemilik saham dan hak khusus yang dimilikinya berkaitan dengan kepemilikan saham. Contohnya adalah hak mendapatkan pendapatan tetap dari perusahaan disamping punya kewajiban untuk ikut menanggung risiko bila perusahaan dilikuidasi. Pemilik saham juga berhak mengontrol perusahaan sesuai dengan kapasitas (jumlah) saham yang dimilikinya melalui rapat umum pemegang saham dengan menggunakan hak suara yang dimilikinya.

Investasi dengan membeli saham suatu perusahaan, berarti investor telah menginvestasikan dana dengan harapan akan mendapatkan keuntungan dari hasil penjualan kembali saham tersebut. Wujud saham adalah selembar kertas yang menerangkan bahwa pemilik kertas tersebut adalah pemilik perusahaan yang menerbitkan surat berharga tersebut dan porsi kepemilikan ditentukan oleh seberapa besar penyertaan yang ditanamkan dalam perusahaan tersebut (Darmadji dan Fakhruddin, 2012:5).

\section{Debt to EquityRatio}

Debt to equity ratio menunjukkan perbandingan antara hutang dengan modal sendiri (Husnan, 2012:70). sedangkan menurut Sawir (2012:03) debt to equity ratio adalah rasio menggambarkan perbandingan utang dan ekuitas dalam pendanaan perusahaan dan menunjukkan kemampuan modal sendiri perusahaan tersebut utuk memenuhi seluruh kewajibannya.

Rasio ini digunakan untuk mengukur seberapa besar jumlah aktiva perusahaan dibiayai dengan utang. Semakin tinggi rasio ini berarti semakin besar jumlah modal pinjaman yang digunakan untuk investasi pada aktiva guna menghasilkan keuntungan bagi perusahaan. Rumusan untuk mencari DAR dapat digunakan sebagai berikut (Kasmir, 2012:156).

Menurut Riyanto (2010:32), rasio utang dimaksudkan sebagai kemampuan suatu perusahaan untuk membayar semua utang-utangnya (baik hutang jangka pendek maupun utang jangka panjang).

\section{Earning Per Share}

Menurut Tandelilin (2010:373), earning per share adalah laba bersih setelah bunga dan pajak yang siap dibagikan kepada pemegang saham dibagi dengan jumlah lembar saham perusahaan.

Menurut Baridwan (2012:443), laba bersih per saham adalah jumlah pendapatan yang diperoleh dalam satu periode untuk tiap lembar saham yang beredar, dan akan dipakai oleh pimpinan perusahaan untuk menentukan besarnya dividen yang akan dibagikan.

Earning per share yang besar menandakan kemampuan perusahaan yang lebih besar dalam menghasilkan 
keuntungan bersih dari setiap lembar saham. Peningkatan earning per share menandakan bahwa perusahaan berhasil meningkatkan taraf kemakmuran investor, dan hal ini akan mendorong investor untuk menambah jumlah modal yang ditanamkan pada perusahaan. Semakin tinggi nilai earning per share akan menggembirakan pemegang saham karena semakin besar laba yang disediakan untuk pemegang saham (Darmadji dan Fakhruddin, 2012:139).

Variabel EPS merupakan proksi bagi laba per saham perusahaan yang diharapkan dapat memberikan gambaran bagi investor mengenai bagian keuntungan yang dapat diperoleh dalam suatu periode tertentu dengan memiliki suatu saham. Seorang investor membeli dan mempertahankan saham suatu perusahaan dengan harapan akan memperoleh deviden atau capital gain. Laba biasanya menjadi dasar penentuan pembayaran deviden dan kenaikan nilai saham di masa mendatang (Prastowo, 2012:93). Oleh karena itu, para pemegang saham biasanya tertarik dengan angka EPS yang dilaporkan perusahaan.

Menurut Brigham dan Weston (2012:26), salah satu faktor yang mempengaruhi harga saham adalah laba per lembar saham (earning per share). Seorang investor yang melakukan investasi pada perusahaan akan menerima laba atas saham yang dimilikinya. Semakin tinggi laba per lembar saham (earning per share) yang diberikan perusahaan akan memberikan pengembalian yang cukup baik. Ini akan mendorong investor untuk melakukan investasi yang lebih besar lagi sehingga harga saham perusahaan akan meningkat.

\section{Price Earning Ratio}

Menurut Sugiyanto (2008:26), Price Earning Ratio adalah rasio yang diperoleh dari harga pasar saham biasa dibagi dengan laba perusahaan. Maka semakin tinggi rasio akan mengindikasikan bahwa kinerja perusahaan semakin membaik, sebaliknya jika Price Earning Ratio terlalu tinggi juga dapat mengindikasikan bahwa harga saham yang ditawarkan sudah tinggi atau tidak rasional.

Menurut Bringham dan Hauston (2010:150), Price Earning Ratio adalah harga saham terhadap laba per saham menunjukkan jumlah yang rela dibayarkan oleh investor untuk setiap dolar laba yang dilaporkan.

Sedangkan menurut Jogianto (2013:105) Price Earning Ratio adalah rasio harga saham terhadap Price Earning Ratio lain dengan kata lain menunjukkan seberapa besar pemodal menilai harga saham terhadap kelipatan dari Earnings.

Dari apa yang dikemukakan oleh Husnan (2012: 155) ternyata bahwa salah satu yang mempengaruhi Price Earning Ratio adalah menaksir harga saham dengan mendasarkan diri atas pertumbuhan laba.

Informasi PER mengidentifikasi besarnya rupiah yang harus dibayarkan investor untuk memperoleh satu rupiah earning perusahaan. Dengan kata lain, PER menunjukkan besarnya harga setiap satu rupiah earning perusahaan. Di samping itu, PER merupakan ukuran harga relative dari sebuah saham perusahaan (Tandellin, 2010:375).

Menurut Darmadji dan Fakhruddin (2012:156) PER menggambarkan apresiasi pasar terhadap kemampuan perusahaan dalam menghasilkan laba. Bagi investor, semakin tinggi PER suatu saham makin bagus karena saham tersebut termasuk murah. Jadi, dapat disimpulkan bahwa PER memiliki pengaruh secara langsung terhadap harga saham, dimana PER melihat bagaimana pasar menghargai kinerja perusahaan yang dicerminkan oleh EPS-nya. 
Pengaruh Earning Per Share (EPS) terhadap Debt To Equity Ratio (DER)

Signalling theory menjelaskan mengapa perusahaan mempunyai dorongan untuk memberikan informasi laporan keuangan pada pihak eksternal. Dorongan perusahaan untuk memberikan informasi karena terdapat asimetri informasi antara perusahaan dan pihak luar karena perusahaan mengetahui lebih banyak mengenai perusahaan dan prospek yang akan datang daripada pihak luar (investor dan kreditur). Pada umumnya perusahaan lebih menyukai pendapatan yang mereka terima digunakan sebagai sumber utama dalam pembiayaan untuk investasi. Apabila sumber dari dalam perusahaan tidak mencukupi maka alternatif lain yang digunakan adalah dengan menggunakan hutang baru kemudian mengeluarkan saham baru sebagai alternatif terakhir untuk pembiayaan. Debt to Equity Ratio perusahaan ini akan mencerminkan permintaan kumulatif untuk pembiayaan yang eksternal. Perusahaan yang dapat menghasilkan laba yang besar dengan tingkat pertumbuhan yang lambat akan mempunyai tingkat debt ratio yang rendah jika dibanding dengan rata-rata industri yang ada. Sabir dan Malik (2012) menyatakan bahwa profitabilitas berpengaruh negatif terhadap struktur modal. Meningkatnya profitabilitas perusahaan akan menyebabkan perusahaan lebih memilih menggunakan modal sendiri yaitu laba ditahan sehingga nilai hutang perusahaan akan menurun.

$\mathrm{H}_{1}=$ Terdapat pengaruh earning per share (EPS) terhadap debt to equity ratio (DER)

\section{Pengaruh Price Earning Ratio (PER)} terhadap Debt To Equity Ratio (DER)

Investasi adalah menyimpan uang atau mengeluarkan uang dengan harapan suatu saat dapat keuntungan finansial. Setiap penggunaan investasi dimaksudkan untuk meningkatkan kemakmuran pemodal (Husnan, 2012: 153). Menurut Brigham dan Houston (2012:36) isyarat atau signal adalah suatu tindakan yang diambil perusahaan untuk memberi petunjuk bagi investor tentang bagaimana manajemen memandang prospek perusahaan. Sinyal ini berupa informasi mengenai apa yang sudah dilakukan oleh manajemen untuk merealisasikan keinginan pemilik. Menurut Pertiwi dan Artini (2012) keputusan investasi yang diproksikan dengan Price Earning Ratio memiliki pengaruh positif terhadap struktur modal. Keputusan investasi merupakan keputusan menyangkut pengalokasian dana berasal dari dalam dan luar perusahaan dalam berbagai bentuk investasi. Semakin besar PER suatu saham menyatakan saham tersebut. Semakin mahal terhadap pendapatan bersih per sahamnya. Dengan demikian semakin besar nilai PER suatu perusahaan semakin tinggi jumlah utang. Peningkatan PER yang dinilai oleh investor menunjukkan kinerja yang semakin baik, juga berdampak semakin menarik perhatian calon kreditor. Meningkatnya perhatian kreditor terhadap perusahaan, maka sangat dimungkinkan jumlah hutang akan semakin meningkat. Peningkatan jumlah utang yang relatif besar dari modal sendiri akan meningkatkan PER

$\mathrm{H}_{2}=$ Terdapat pengaruh price earning ratio (PER) terhadap debt to equity ratio (DER)

\section{Pengaruh Earning Per Share (EPS) terhadap Harga Saham}

Pertumbuhan profitabilitas perusahaan juga merupakan indikator yang sangat penting diperhatikan untuk mengetahui sejauh mana investasi yang akan dilakukan oleh investor di suatu perusahaan mampu memberikan return yang sesuai dengan tingkat yang 
disyaratkan investor. Husnan (2012:391) menyatakan bahwa EPS yang tinggi menandakan perusahaan tersebut mampu memberikan tingkat kesejahteraan yang lebih baik kepada pemegang saham, sedangkan EPS yang rendah menandakan bahwa perusahaan gagal memberikan manfaat sebagaimana diharapkan oleh pemegang saham. Signalling theory menjelaskan mengapa perusahaan mempunyai dorongan untuk memberikan informasi laporan keuangan pada pihak eksternal. Dorongan perusahaan untuk memberikan informasi karena terdapat asimetri informasi antara perusahaan dan pihak luar karena perusahaan mengetahui lebih banyak mengenai perusahaan dan prospek yang akan datang daripada pihak luar (investor dan kreditur). Menurut Hamka (2012) Earning per Share berpengaruh positif terhadap harga saham. Earning per Share dapat dinilai kemampuan perusahaan dalam membagikan labanya kepada para pemegang saham. Semakin tinggi laba perusahaan yang diberikan kepada para pemegang saham akan menambah daya tarik investor dan mendorong untuk memiliki saham tersebut, sehingga menyebabkan meningkatnya harga saham. Keterangan tersebut menunjukkan bahwa Earning per Share mempunyai pengaruh positif terhadap harga saham perusahaan.

$\mathrm{H}_{3}=$ Terdapat pengaruh earning per share (EPS) terhadap harga saham

\section{Pengaruh Price Earning Ratio (PER) terhadap Harga Saham}

Price Earning Ratio (PER) atau biasa disebut $\mathrm{P} / \mathrm{E}$ Ratio merupakan rasio pasar yang digunakan untuk melihat bagaimana pasar menghargai kinerja saham suatu perusahaan terhadap kinerja perusahan yang dicerminkan oleh EPS (Earning Per Share)-nya. Semakin besar $\mathrm{P} / \mathrm{E}$ Ratio suatu saham, maka saham tersebut akan semakin mahal terhadap pendapatan bersih per lembar sahamnya. Jika dikatakan saham mempunyai $\mathrm{P} / \mathrm{E}$ Ratio 10 kali, berarti harga saham tersebut 10 kali lipat terhadap EPS-nya (pendapatan bersih per lembar saham). Saham yang mempunyai P/E Ratio semakin kecil akan semakin bagus, yang berarti saham tersebut semakin murah. Menurut Brigham dan Houston (2012:36) isyarat atau signal adalah suatu tindakan yang diambil perusahaan untuk memberi petunjuk bagi investor tentang bagaimana manajemen memandang prospek perusahaan. Sinyal ini berupa informasi mengenai apa yang sudah dilakukan oleh manajemen untuk merealisasikan keinginan pemilik. Menurut Dewi dan Sudiartha (2013) PER terhadap harga saham berpengaruh negatif terhadap harga saham. Ini berarti dikarenakan bahwa investor cenderung berinvestasi pada perusahaan yang memiliki nilai PER rendah. Bahwa pada periode ini, investor tidak melihat harga saham sebagai acuan dalam berinvestasi, tetapi investor menggunakan tingkat laba per lembar saham oleh yang dikeluarkan oleh perusahaan. Dalam hal ini nilai PER yang rendah dapat menunjukkan bahwa tingkat laba per lembar saham yang dihasilkan oleh suatu perusahaan adalah rendah yang jika dibandingkan pada harga saham tersebut.

$\mathrm{H}_{4}=$ Terdapat pengaruh price earning ratio (PER) terhadap harga saham

\section{Pengaruh Debt To Equity Ratio (DER) terhadap Harga Saham}

Menurut Jogiyanto (2011: 392) informasi yang dipublikasikan sebagai suatu pengumuman akan memberikan sinyal bagi investor dalam pengambilan keputusan investasi. Saat informasi diumumkan dan diterima pelaku pasar, pelaku pasar terlebih dahulu menginterpretasikan dan menganalisis informasi tersebut sebagai signal baik (good news) atau signal buruk (bad 
news). Menurut Mulyadi dalam Sisca, (2010:9), Debt to equity ratio menggambarkan perbandingan antara total hutang dengan total ekuitas perusahaan yang digunakan sebagai sumber pendanaan usaha. Debt to equity ratio mengungkapkan bagaimana penggunaan pendanaan perusahaan dari struktur modal yang dimiliki oleh perusahaan yang berasal dari utang jangka panjang dan modal yang berasal dari ekuitas. Semakin besar DER menandakan struktur permodalan usaha lebih banyak memanfaatkan utang-utang relatif terhadap ekuitas dan mencerminkan risiko perusahaan yang relatif tinggi. Menurut Irkham, dkk (2014) DER berpengaruh signifikan positif terhadap harga saham, artinya

\section{Rerangka Konseptual}

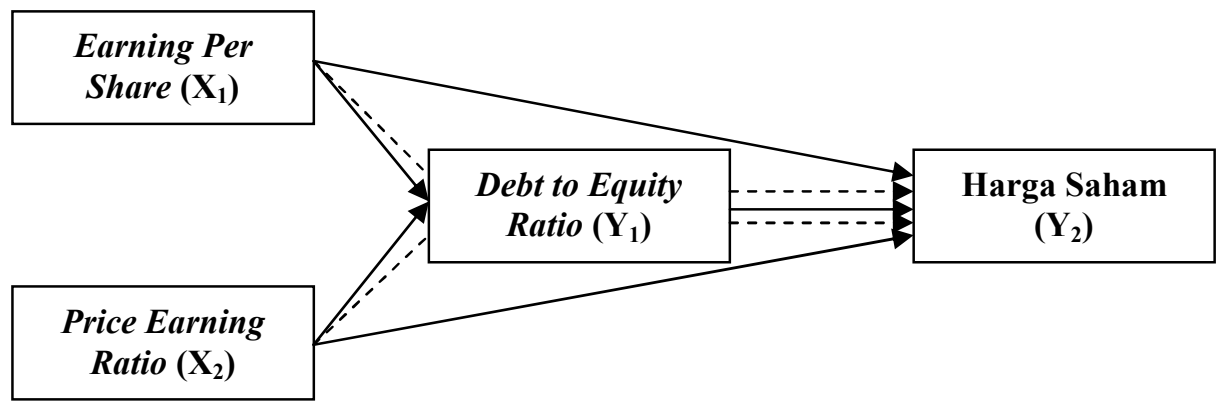

Gambar 1: Rerangka Konseptual

Keterangan: semakin tinggi nilai DER maka akan semakin tinggi pula harga saham. Debt to equity ratio mengungkapkan bagaimana penggunaan pendanaan perusahaan dari struktur modal yang dimiliki oleh perusahaan yang berasal dari utang jangka panjang dan modal yang berasal dari ekuitas. DER berpengaruh positif terhadap harga saham menunjukkan bahwa investor memperhatikan berapa besar modal yang dibiayai oleh mereka kepada perusahaan untuk menghasilkan laba bersih untuk mereka. Semakin besar DER menandakan struktur permodalan usaha lebih banyak memanfaatkan dana yang disediakan oleh kreditur untuk menghasilkan laba.

$\mathrm{H}_{5}=$ Terdapat pengaruh debt to equity ratio (DER) terhadap harga saham

$\begin{aligned} \longrightarrow & =\text { Pengaruh langsung } \\ & =\text { Pengaruh tidak langsung }\end{aligned}$

\section{METODE PENELITIAN Rancangan Penelitian}

Desain penelitian yang digunakan dalam penelitian ini adalah deskriptif kuantitatif. Metode pengumpulan data melalui dokumentasi. Analisis data untuk pengujian hipotesis pada penelitian ini menggunakan analisis jalur (Path Analys).

\section{Definisi Operasional dan Pengukuran} Variabel

Penelitian ini menggunakan variabel sebagai berikut:
1. Harga Saham. Harga saham merupakan harga pasar yang tercatat pada waktu penutupan (closing price) aktivitas di Bursa Efek Indonesia. Dengan menggunakan skala ratio satuan rupiah. Pada penelitian ini menggunakan harga saham selama 2010-2014.

2. Debt to Equity Ratio. Debt to equity ratio merupakan rasio yang digunakan untuk mengukur seberapa besar jumlah aktiva perusahaan dibiayai dengan utang. Dengan menggunakan skala ratio satuan persen $(\%)$. Debt to 
equity ratio diukur dengan rumus sebagai berikut:

Debt to Equity Retio $=\frac{\text { Total Utang }}{\text { Equitas }} \mathrm{x} 100 \%$

Sawir (2012:13)

3. Earning Per Share. Earning per share merupakan jumlah pendapatan yang diperoleh dalam satu periode untuk tiap lembar saham yang beredar. Dengan menggunakan skala ratio satuan persen (\%). Earning per share diukur dengan rumus sebagai berikut:

Exning Per Share $=\frac{\text { Laba Bersih }}{\text { Iumlah Saham Beredar }}$

Sumber: Darmadji dan Fakhruddin (2012:154)

4. Price Earning Ratio. Price earning ratio merupakan rasio yang diperoleh dari harga pasar saham biasa dibagi dengan laba perusahaan. Dengan menggunakan skala ratio satuan persen (\%). Price earning ratio diukur dengan rumus sebagai berikut:

Frice Erming Tatio $=\frac{\text { Harga 5aham. }}{\text { Eaming Per Share }} \times$
Darmadji dan Fakhruddin (2012:156)

\section{Jenis, Sumber dan Teknik Pengumpulan Data}

Jenis data yang digunakan dalam penelitian ini adalah kuantitatif. Data yang digunakan dalam penelitian ini adalah laporan keuangan perusahaan sector makanan dan minuman.

Sumber data dalam penelitian ini adalah data sekuder. Data yang digunakan dalam penelitian ini adalah laporan keuangan dan harga saham dari tahun 2010 sampai 2014.

x100\% Adapun teknik pengumpulan data yang digunakan oleh peneliti dalam penelitian ini adalah studi pustaka atau studi dokumentasi. Data yang digunakan dalam penelitian ini diperoleh dari web Bursa Efek Indonesia (www.idx.com).

\section{Populasi dan Sampel}

Populasi yang digunakan dalam penelitian ini adalah perusahaan sektor makanan dan minuman di Bursa Efek Indonesia (BEI) sebanyak 17 perusahaan. 100\%6Sampel yang digunakan dalam penelitian ini tampak pada tabel berikut:

\begin{tabular}{cl} 
Kode & \multicolumn{1}{c}{ Nama Perusahaan } \\
ADES & Akasha Wira International Tbk, \\
AISA & Tiga Pilar Sejahtera Food Tbk \\
CEKA & Wilmar Cahaya Indonesia Tbk \\
DLTA & Delta Djakarta Tbk \\
ICBP & Indofood CBP Sukses Makmur Tbk \\
INDF & Indofood Sukses Makmur Tbk \\
MLBI & Multi Bintang Indonesia Tbk
\end{tabular}

Sumber: www.idx.com

\section{Teknik Analisis}

\section{Uji Asumsi Klasik}

1. Uji Normalitas, yang bertujuan untuk mengetahui apakah masing-masing variabel berdistribusi normal atau tidak (Ghozali ,2013)

2. Uji Heteroskedastisitas yang bertujuan untuk menguji apakah dalam model regresi terjadi ketidaksamaan variance dari residual satu pengamatan ke

\author{
Kode \\ Kode \\ MYOR Mayora Indah Tbk \\ PSDN Prashida Aneka Niaga Tbk \\ ROTI Nippon Indosari Corporindo Tbk \\ SKBM Sekar Bumi Tbk \\ SKLT Sekar Laut Tbk \\ STTP Siantar Top Tbk \\ ULTJ Ultrajaya Milk Industry and Trading \\ Company Tbk
}

pengamatan lain, jika variance dari residual satu pengamatan ke pengamatan lain berbeda maka disebut heteroskedastisitas (Ghozali ,2013)

3. Uji Multikolineritas yang bertujuan untuk menguji apakah dalam model regresi ditemukan adanya korelasi antar variabel-variabel bebas (Ghozali ,2013) 
4. Uji Autokorelasi yang bertujuan untuk menguji apakah dalam model regresi linear ada korelasi antara kesalahan pengganggu pada periode $\mathrm{t}$ dengan kesalahan pengganggu pada periode $\mathrm{t}$ 1 (sebelumnya). Jika terjadi korelasi maka dinamakan ada problem autokorelasi (Ghozali, 2013).

\section{Persamaan Regresi}

Teknik analisis yang digunakan dalam penelitian ini menggunakan path analysis. Path Analysis digunakan untuk menguji pengaruh variabel intervening. Analisis jalur merupakan perluasan dari analisis regresi linear berganda, atau analisis jalur digunakan untuk menganalisis pola hubungan antar variabel dengan tujuan untuk mengetahui pengaruh langsung maupun tidak langsung seperangkat variabel bebas (eksogen) terhadap variabel terikat (endogen) (Ghozali, 2013: 174).

Berdasarkan kerangka dasar konseptual, dapat dibuat persamaan struktur sebagai berikut:
$\mathrm{Y}_{1}=\beta \mathrm{Y}_{1} \mathrm{X}_{1}+\beta \mathrm{Y}_{1} \mathrm{X}_{2}+\mathrm{e}_{1}$
$\mathrm{Y}_{2}=\beta \mathrm{Y}_{2} \mathrm{X}_{1}+\beta \mathrm{Y}_{2} \mathrm{X}_{2}+\beta \mathrm{Y}_{2} \mathrm{Y}_{1}+\mathrm{e}_{2}$
$\mathrm{Y}_{2}=\beta \mathrm{Y}_{1} \mathrm{X}_{1} \times \beta \mathrm{Y}_{2} \mathrm{Y}_{1}$
$\mathrm{Y}_{2}=\beta \mathrm{Y}_{1} \mathrm{X}_{2} \times \beta \mathrm{Y}_{2} \mathrm{Y}_{1}$
Keterangan:
$\mathrm{X}_{1}=$ Earning Per Share
$\mathrm{X}_{2}=$ Price Earning Ratio
$\mathrm{Y}_{1}=$ Debt to Equity Ratio
$\mathrm{Y}_{2}=$ Harga Saham
$\beta=$ Koefisien path pengaruh langsung
e $=$ Standart error

\section{Uji Parsial (Uji T)}

Khusus untuk program SPSS menu analisis regresi, koefisien path ditunjukkan oleh output yang dinamakan coefficient yang dinyatakan sebagai standardized coefficient atau dikenal dengan nilai Beta. Jika ada diagram jalur sederhana mengandung satu unsur hubungan antara variabel eksogen dengan variabel endogen, maka koefisien path-nya adalah sama dengan koefisien korelasi r sederhana.

\section{Uji Intervening}

Menurut Baron \& Kenny (1986) suatu variabel disebut variabel intervening jika variabel tersebut ikut mempengaruhi hubungan antara variabel independent dan variabel dependent. Pengujian hipotesis mediasi dapat dilakukan dengan prosedur yang dikembangkan oleh Sobel (1982) dan dikenal dengan Uji Sobel (sobel test).

Koefisien Determinasi $\left(\mathbf{R}^{2}\right)$

Koefisien determinasi (R2) pada intinya mengukur seberapa jauh kemampuan model dalam menerangkan variasi variabel independen. Nilai koefisien determinasi adalah antara nol dan satu. Nilai R2 yang kecil berarti kemampuan variabel-variabel independen dalam menjelaskan variasi variabel dependen sangat terbatas. Nilai yang mendekati satu berarti variabel-variabel independen memberikan hampir semua informasi yang dibutuhkan untuk memprediksi variasi variabel dependen (Ghozali, 2013)

\section{HASIL PENELITIAN DAN PEMBAHASAN \\ Deskripsi Data}

Deskripsi variabel dalam statistik deskriptif yang digunakan pada penelitian ini meliputi mean dan standar deviasi dari satu variabel dependen dan independen. Tujuan dari statistik deskriptif ini untuk mengetahui sejauh mana karakter dari sampel yang digunakan dalam penelitian. Berdasarkan hasil analisis deskriptif statistik, karakteristik sampel yang digunakan di dalam penelitian ini meliputi jumlah sampel (N), rata-rata sampel (mean) serta standar deviasi, untuk masing-masing variabel. Berdasarkan data tabel diatas dapat diketahui nilai rata-rata dan standar deviasi Price Earning Ratio (PER), Earning Per Share (EPS), Debt to Equity Ratio (DER) dan harga saham sebagai berikut: 
Tabel 2: Nilai Rata-rata dan Standar Deviasi

\begin{tabular}{lrr}
\hline \multicolumn{1}{c}{ Variabel } & Rata-rata & \multicolumn{1}{c}{ Standar Deviasi } \\
\hline Harga saham & $240.672,84$ & $174.525,12$ \\
\hline Debt to Equity Ratio (DER) & 8,49 & 2,45 \\
\hline Earning Per Share (EPS) & 0,36 & 0,20 \\
\hline Price Earning Ratio (PER) & 16,73 & 2,97 \\
\hline Sumber: Data sekunder diolah, 2016 & &
\end{tabular}

Berdasarkan tabel diatas tampak bahwa rata-rata harga saham sebesar $240.672,84$ artinya rata-rata harga saham perusahaan sektor makanan dan minuman selama tahun 2010-2014 sebesar 240.672,84 dengan standar deviasi sebesar 174.525,12. Harga pasar adalah harga jual dari investor yang satu dengan investor yang lain. Harga pasar merupakan harga yang benar-benar mewakili harga perusahaan penerbitnya, karena pada transaksi di pasar sekunder, kecil sekali terjadi negosiasi harga antara investor dengan perusahaan penerbit.

Rata-rata Debt to Equity Ratio (DER) sebesar 8,49 artinya rata-rata modal perusahaan yang dibiayai dengan utang perusahaan sektor makanan dan minuman selama tahun 2010-2014 sebesar 8,49 dengan standar deviasi sebesar 2,45. Debt to equity ratio menunjukkan perbandingan antara hutang dengan modal sendiri. Semakin tinggi Debt to equity ratio berarti semakin besar jumlah modal pinjaman yang digunakan untuk investasi pada aktiva guna menghasilkan keuntungan bagi perusahaan.

Rata-rata Earning Per Share (EPS) sebesar 0,36 artinya rata-rata laba perusahaan yang didapatkan dari per lembar saham perusahaan sektor makanan dan minuman selama tahun 2010-2014 sebesar 0,36 dengan standar deviasi sebesar 0,20. Earning per share yang besar menandakan kemampuan perusahaan yang lebih besar dalam menghasilkan keuntungan bersih dari setiap lembar saham. Peningkatan earning per share menandakan bahwa perusahaan berhasil meningkatkan taraf kemakmuran investor, dan hal ini akan mendorong investor untuk menambah jumlah modal yang ditanamkan pada perusahaan.

Rata-rata Price Earning Ratio (PER) sebesar 16,73 artinya rata-rata modal perusahaan yang digunakan untuk kegiatan investasi perusahaan sektor makanan dan minuman selama tahun 2010-2014 sebesar 16,73 dengan standar deviasi sebesar 2,97. Price Earning Ratio adalah rasio yang diperoleh dari harga pasar saham biasa dibagi dengan laba perusahaan. Semakin tinggi rasio akan mengindikasikan bahwa kinerja perusahaan semakin membaik, sebaliknya jika Price Earning Ratio terlalu tinggi juga dapat mengindikasikan bahwa harga saham yang ditawarkan sudah tinggi atau tidak rasional.

\section{Uji Asumsi Klasik}

\section{Uji Normalitas}

Distribusi normal merupakan distribusi teoritis dari variabel random yang kontinyu. Berdasarkan hasil olah data menggunakan SPSS, diketahui bahwa data menyebar disekitar garis diagonal dan mengikuti arah garis diagonal pada grafik histogram, hal ini menunjukkan bahwa pola distribusi normal. Jadi dapat disimpulkan bahwa berdasarkan grafik P-P plot, model regresi memenuhi asumsi normalitas

\section{Uji Heteroskedastisitas}

Uji gejala heteroskedastisitas bertujuan untuk menguji apakah dalam model regresi terjadi ketidaksamaan varians dari residual pada satu pengamatan ke pengamatan yang lain. Berdasarkan hasil olah data menggunakan SPSS diketahui bahwa 
tidak ada pola yang jelas serta titik-titik tersebut menyebar di atas dan di bawah angka 0 pada sumbu $Y$. Hal ini menunjukkan bahwa data dalam penelitian ini tidak terjadi heteroskedastisitas.

\section{Uji Multikolineritas}

Pengujian terhadap gejala multikolinieritas ini dilakukan untuk mengetahui apakah ada korelasi yang serius antar variabel independen yang digunakan dalam model regresi. Berdasarkan hasil olah data menggunakana SPSS menunjukkan bahwa nilai VIF semua variabel bebas dalam penelitian ini lebih kecil dari 10 sedangkan nilai toleransi semua variabel bebas lebih besar dari 0,10 yang berarti tidak terjadi korelasi antar variabel bebas, dengan demikian dapat disimpulkan bahwa tidak terdapat gejala multikolinieritas antar variabel bebas.

\section{Uji Autokorelasi}

Autokorelasi yaitu adanya hubungan antara kesalahan-kesalahan yang muncul (error term) pada data runtun waktu (time series). Hasil pengujian dengan menggunakan DurbinWatson Statistic (DW) menunjukkan nilai dW-hitung sebesar 2,146. Sedangkan nilai Tabel $\mathrm{dW}$ untuk data observasi (n) sebanyak 70 dan variabel 3 independen (k) pada Tabel DurbinWatson akan diperoleh nilai batas atas $(\mathrm{dU})=1,524$ dan batas bawah $(\mathrm{dL})=$ 1,702, sedangkan nilai 4-dU $=2,298$. Karena nilai DW 2,146 lebih besar dari batas atas (du) 1,1769 dan kurang dari 4 1.73 (2.267) atau $(1,524<2,146<$ 2,298), maka dapat disimpulkan bahwa tidak terdapat autokorelasi.

\section{Persamaan Regresi}

\section{Pengaruh Earning Per Share (EPS) dan Price Earning Ratio (PER) Terhadap Debt to Equity Ratio (DER)}

Berdasarkan hasil SPSS dapat diketahui pesamaan regresi sebagai berikut:

Tabel 3: Unstandardized Coefficients

\begin{tabular}{|c|c|c|c|c|c|c|c|}
\hline \multicolumn{8}{|c|}{ Coefficients $^{\mathrm{a}}$} \\
\hline \multirow[t]{2}{*}{ Model } & \multicolumn{2}{|c|}{$\begin{array}{c}\text { Unstandardized } \\
\text { Coefficients }\end{array}$} & \multirow{2}{*}{$\begin{array}{c}\begin{array}{c}\text { Standardized } \\
\text { Coefficients }\end{array} \\
\text { Beta } \\
\end{array}$} & \multirow[t]{2}{*}{$\mathrm{t}$} & \multirow[t]{2}{*}{ Sig. } & \multicolumn{2}{|c|}{$\begin{array}{c}\text { Collinearity } \\
\text { Statistics }\end{array}$} \\
\hline & $\mathrm{B}$ & Std. Error & & & & Tolerance & VIF \\
\hline (Constant) & .817 & .115 & & 7.117 & .000 & & \\
\hline$1 \longdiv { \mathrm { EPS } }$ & -.288 & .116 & -.287 & -2.488 & .015 & 1.000 & 1.000 \\
\hline PER & .154 & .115 & .154 & 1.332 & .187 & 1.000 & 1.000 \\
\hline
\end{tabular}

Sumber: Data sekunder diolah, 2016

Berdasarkan tabel diatas persamaan regresinya adalah: $\mathbf{Y}=\mathbf{0 , 8 1 7}-\mathbf{0 , 2 8 8}+$ 0,154

1. Nilai konstanta adalah sebesar 0,817 artinya jika semua variabel independen dianggap konstan 0 (nol) maka nilai Debt to Equity Ratio (DER) adalah sebesar $81,7 \%$.

2. Earning Per Share (EPS) mempunyai koefisien regresi dengan arah negatif sebesar 0,288. Jika diasumsikan variabel independen lain konstan, hal ini berarti setiap peningkatan Earning
Per Share (EPS) sebesar 1 persen maka Debt to Equity Ratio perusahaan akan mengalami penurunan sebesar 28,8 persen.

3. Price Earning Ratio (PER) mempunyai koefisien regresi dengan arah positif sebesar 0,154. Jika diasumsikan variabel independen lain konstan, hal ini berarti setiap peningkatan Price Earning Ratio (PER)sebesar 1 persen maka Debt to Equity Ratio perusahaan akan mengalami peningkatan sebesar $15,4 \%$ 
2. Pengaruh Earning Per Share (EPS), Price Earning Ratio (PER) dan Debt to Equity Ratio (DER) Terhadap Harga Saham
Berdasarkan hasil SPSS dapat diketahui pesamaan regresi sebagai berikut:

Tabel 4: Unstandardized Coefficients

\begin{tabular}{|c|c|c|c|c|c|c|c|c|}
\hline \multicolumn{9}{|c|}{ Coefficients $^{\mathrm{a}}$} \\
\hline \multirow{2}{*}{\multicolumn{2}{|c|}{ Model }} & \multicolumn{2}{|c|}{$\begin{array}{l}\text { Unstandardized } \\
\text { Coefficients }\end{array}$} & \multirow{2}{*}{$\begin{array}{c}\begin{array}{c}\text { Standardized } \\
\text { Coefficients }\end{array} \\
\text { Beta } \\
\end{array}$} & \multirow[t]{2}{*}{$\mathrm{t}$} & \multirow[t]{2}{*}{ Sig. } & \multicolumn{2}{|c|}{$\begin{array}{l}\text { Collinearity } \\
\text { Statistics }\end{array}$} \\
\hline & & B & Std. Error & & & & Tolerance & VIF \\
\hline \multirow{4}{*}{1} & (Constant) & -.816 & .001 & & -1128.817 & .000 & & \\
\hline & EPS & -.001 & .001 & -.001 & -2.357 & .021 & .915 & 1.093 \\
\hline & PER & .001 & .001 & .001 & 2.048 & .045 & .974 & 1.027 \\
\hline & DER & .999 & .001 & .999 & 1.721 & .000 & .893 & 1.120 \\
\hline
\end{tabular}

a. Dependent Variable: SAHAM

Sumber: Data Sekunder diolah, 2016

Berdasarkan tabel diatas menunjukkan bahwa persamaan regresi sebagai berikut: $\mathbf{Y}=\mathbf{- 0 , 8 1 6}-\mathbf{0 , 0 0 1}+\mathbf{0 , 0 0 1}+\mathbf{0 , 9 9 9}$

1. Nilai konstanta adalah sebesar 0,816 artinya jika semua variabel independen dianggap konstan 0 (nol) maka nilai harga saham adalah sebesar $81,6 \%$.

2. Earning Per Share (EPS) mempunyai koefisien regresi dengan arah negatif sebesar 0,001. Jika diasumsikan variabel independen lain konstan, hal ini berarti setiap penurunan Earning Per Share (EPS) sebesar 1 persen maka harga saham perusahaan akan mengalami peningkatan sebesar 0,1 persen.

3. Price Earning Ratio (PER) mempunyai koefisien regresi dengan arah positif sebesar 0,001. Jika diasumsikan variabel independen lain konstan, hal ini berarti setiap peningkatan Price Earning Ratio (PER)sebesar 1 persen maka harga saham perusahaan akan mengalami peningkatan sebesar 0,1 persen
4. Debt to Equity Ratio (DER) mempunyai koefisien regresi dengan arah positif sebesar 0,999. Jika diasumsikan variabel independen lain konstan, hal ini berarti setiap peningkatan Debt to Equity Ratio (DER) sebesar 1 persen maka harga saham perusahaan akan mengalami peningkatan sebesar 99,9 persen

\section{Koefisien Determinasi}

Koefisien determinasi $\left(\mathrm{R}^{2}\right)$ pada intinya mengukur seberapa jauh kemampuan model dalam menerangkan variasi variabel dependen. Besarnya koefisien determinasi ini adalah nol sampai dengan satu $(0<$ RVariabel independen memberikan informasi yang dibutuhkan dalam memprediksi variasi variabel dependen dan akan menunjukkan nilai $\mathrm{R}^{2}$ yang mendekati satu.

Koefisien determinasi $\left(\mathrm{R}^{2}\right)$ Pengaruh Earning Per Share (EPS) dan Price Earning Ratio (PER) Terhadap Debt to Equity Ratio (DER) sebagai berikut:

Tabel 5: Hasil Koefisien Determinasi

\begin{tabular}{|c|c|c|c|c|c|}
\hline \multicolumn{6}{|c|}{ Model Summary ${ }^{b}$} \\
\hline $\begin{array}{l}\text { Mode } \\
1\end{array}$ & $\mathrm{R}$ & R Square & $\begin{array}{l}\text { Adjusted R } \\
\text { Square }\end{array}$ & $\begin{array}{l}\text { Std. Error of the } \\
\text { Estimate }\end{array}$ & $\begin{array}{l}\text { Durbin- } \\
\text { Watson }\end{array}$ \\
\hline 1 & $.328^{\mathrm{a}}$ & .107 & .081 & .96055 & 1.706 \\
\hline \multicolumn{6}{|c|}{ a. Predictors: (Constant), PER, EPS } \\
\hline b. Dep & ent $\mathrm{Var}$ & able: DER & & & \\
\hline
\end{tabular}


Berdasarkan hasil penghitungan pada tabel diatas diketahui bahwa pengaruh kedua variabel independen terhadap variabel dependen dinyatakan dengan nilai koefisien determinasi $\left(\mathrm{R}^{2}\right)$ yaitu sebesar 0,107 atau $10,7 \%$. Hal ini berarti bahwa Earning Per Share (EPS) dan Price Earning Ratio (PER) hanya mampu menjelaskan pengaruhnya terhadap Debt to Equity Ratio (DER) sebesar $10,7 \%$ sedangkan $89,3 \%$ lainnya dijelaskan oleh variabel lainnya yang tidak ada dalam penelitian.

$$
\text { Koefisien determinasi }\left(\mathrm{R}^{2}\right)
$$

Pengaruh Earning Per Share (EPS), Price Earning Ratio (PER) dan Debt to Equity Ratio (DER) terhadap harga saham sebagai berikut:

Tabel 6: Hasil Koefisien Determinasi

\begin{tabular}{|c|c|c|c|c|c|}
\hline \multicolumn{6}{|c|}{ Model Summary ${ }^{b}$} \\
\hline Model & $\mathrm{R}$ & R Square & $\begin{array}{l}\text { Adjusted R } \\
\text { Square }\end{array}$ & $\begin{array}{l}\text { Std. Error of the } \\
\text { Estimate }\end{array}$ & $\begin{array}{l}\text { Durbin- } \\
\text { Watson }\end{array}$ \\
\hline 1 & $.624^{\mathrm{a}}$ & .390 & .300 & .82670 & 2.146 \\
\hline \multicolumn{6}{|c|}{ a. Predictors: (Constant), DER, PER, EPS } \\
\hline b. Dep & Varia & le: SAHAN & & & \\
\hline
\end{tabular}

Berdasarkan hasil penghitungan pada tabel diatas diketahui bahwa pengaruh tiga variabel independen terhadap variabel dependen dinyatakan dengan nilai koefisien determinasi $\left(\mathrm{R}^{2}\right)$ yaitu sebesar 0,390 atau $39 \%$. Hal ini berarti bahwa Earning Per Share (EPS), Price Earning Ratio (PER) dan Debt to Equity Ratio (DER) hanya mampu menjelaskan pengaruhnya terhadap harga saham sebesar $39 \%$ sedangkan $61 \%$

Tabel 7: Hasil Pengaruh Langsung

\begin{tabular}{lrrr}
\hline \multicolumn{1}{c}{ Variabel } & T hitung & \multicolumn{1}{c}{ Signifikasi } & Z-Value \\
\hline Earning Per Share (EPS) & $-2,488$ & 0,015 & \\
\cline { 1 - 3 } Price Earning Ratio (PER) & 1,332 & 0,187 & 0,944 \\
\hline
\end{tabular}

Sumber: Data sekunder diolah, 2016

Untuk mengetahui nilai $\mathrm{t}$ statistik tabel ditentukan tingkat signifikasi 5\% dengan derajat kebebasan yaitu $\mathrm{df}=(\mathrm{n}-\mathrm{k}-$ 1), dimana $\mathrm{n}=$ jumlah observasi dan $\mathrm{k}=$ jumlah variabel. Pada penelitian ini jumlah observasi sebanyak 70 dan jumlah variabel sebanyak 2 sehingga nilai $\mathrm{df}=$ 67 (70-2-1). Berdasarkan nilai df 67 maka didapatkan nilai $\mathrm{t}$ tabel sebesar 1,667 atau -1,667. Uji parsial masingmasing variabel dapat dijelaskan sebagai berikut:

Pengaruh Earning Per Share (EPS) Terhadap Debt to Equity Ratio (DER) lainnya dijelaskan oleh variabel lainnya yang tidak ada dalam penelitian.

Pengaruh Earning Per Share (EPS) dan Price Earning Ratio (PER) Terhadap Debt to Equity Ratio (DER)

Berdasarkan hasil SPSS dapat diketahui pengaruh langsung Earning Per Share (EPS) dan Price Earning Ratio (PER) terhadap Debt to Equity Ratio (DER) sebagai berikut: 
Earning Per Share (EPS) maka semakin tinggi Debt to Equity Ratio (DER).

Hasil penelitian ini menunjukkan bahwa perusahaan menggunakan utang yang lebih sedikit ketika perusahaan memperoleh keuntungan yang tinggi sehingga lebih memilih menggunakan laba ditahan daripada utang maupun modal yang dimiliki dalam mendanai perusahaan. Perusahaan dengan laba tinggi tentu memiliki dana internal yang lebih besar dari pada perusahaan dengan laba rendah. Karena itu laba akan berhubungan negatif dengan utang perusahaan. Semakin tinggi keuntungan yang diperoleh berarti semakin rendah kebutuhan dana asing (utang) sehingga semakin rendah pula utangnya.

Menurut signalling theory menjelaskan mengapa perusahaan mempunyai dorongan untuk memberikan informasi laporan keuangan pada pihak eksternal. Dorongan perusahaan untuk memberikan informasi karena terdapat asimetri informasi antara perusahaan dan pihak luar karena perusahaan mengetahui lebih banyak mengenai perusahaan dan prospek yang akan datang daripada pihak luar (investor dan kreditur). Pada umumnya perusahaan lebih menyukai pendapatan yang mereka terima digunakan sebagai sumber utama dalam pembiayaan untuk investasi. Apabila sumber dari dalam perusahaan tidak mencukupi maka alternatif lain yang digunakan adalah dengan menggunakan hutang baru kemudian mengeluarkan saham baru sebagai alternatif terakhir untuk pembiayaan.

Hal ini sesuai dengan penelitian yang dilakukan oleh Sabir dan Malik (2012) yang menyatakan bahwa profitabilitas berpengaruh negatif terhadap struktur modal. Meningkatnya profitabilitas perusahaan akan menyebabkan perusahaan lebih memilih menggunakan modal sendiri yaitu laba ditahan sehingga nilai hutang perusahaan akan menurun.

\section{Pengaruh Price Earning Ratio (PER)} Terhadap Debt to Equity Ratio (DER)

Berdasarkan hasil olah data menunjukkan $\mathrm{t}$ hitung Price Earning Ratio (PER) sebesar 1,332 dan t tabel sebesar 1,667 sehingga $t$ hitung lebih kecil dari t tabel $(1,332<1,667)$ artinya tidak terdapat pengaruh positif Price Earning Ratio (PER) terhadap Debt to Equity Ratio (DER). Nilai signifikasi sebesar 0,187 lebih besar dari 0,05 (0,187 $>0,05)$ artinya tidak signifikan.

Dapat disimpulkan bahwa tidak terdapat pengaruh Price Earning Ratio (PER) terhadap Debt to Equity Ratio (DER) artinya bahwa naik turunnya Price Earning Ratio (PER) tidak mempengaruhi naik turunnya Debt to Equity Ratio (DER). Price Earning Ratio (PER) menunjukkan arah positif artinya meskipun tidak mempengaruhi Debt to Equity Ratio (DER) namun semakin tinggi Debt to Equity Ratio (DER).

Price Earning Ratio (PER) tidak berpengaruh terhadap Debt to Equity Ratio (DER) hal ini terjadi karena fluktuasi Price Earning Ratio (PER) tidak besar sehingga tidak mempengaruhi Debt to Equity Ratio (DER). Keputusan investasi merupakan keputusan menyangkut pengalokasian dana berasal dari dalam dan luar perusahaan dalam berbagai bentuk investasi. Keputusan investasi ditentukan seberapa besar nilai Price Earning Ratio (PER). Semakin besar PER suatu saham menyatakan saham tersebut semakin mahal terhadap pendapatan laba bersih per sahamnya. Dengan demikian semakin besar nilai PER suatu perusahaan semakin tinggi jumlah utang. Peningkatan PER yang dinilai oleh investor menunjukkan kinerja yang semakin baik, juga berdampak semakin menarik perhatian calon kreditor. Meningkatnya perhatian kreditor terhadap perusahaan, maka 
sangat dimungkinkan jumlah hutang akan semakin meningkat. Peningkatan jumlah utang yang relatif besar dari modal sendiri akan meningkatkan PER.

Isyarat atau signal adalah suatu tindakan yang diambil perusahaan untuk memberi petunjuk bagi investor tentang bagaimana manajemen memandang prospek perusahaan. Sinyal ini berupa informasi mengenai apa yang sudah dilakukan oleh manajemen untuk merealisasikan keinginan pemilik.

Hal ini sesuai dengan penelitian yang dilakukan Sarasati (2013) yang menyatakan bahwa Price Earning Ratio tidak mempengaruhi struktur modal. Price Earning Ratio (PER) adalah ukuran kinerja saham yang didasarkan atas perbandingan antara harga pasar saham terhadap pendapatan perlembar saham Earning Per Share (EPS). Pertumbuhan laba dan dividen serta expected rate of return dari suatu saham berubah-ubah nilainya, maka PER diharapkan juga akan berubah sepanjang waktu berjalan dan pada akhirnya menuju suatu tingkat nilai PER rata-rata dari saham-saham yang mempunyai tingkat risiko yang sama

Pengaruh Earning Per Share (EPS), Price Earning Ratio (PER) dan Debt to Equity Ratio (DER) Terhadap Harga Saham

Berdasarkan hasil SPSS dapat diketahui pengaruh langsung Earning Per Share (EPS), Price Earning Ratio (PER) dan Debt to Equity Ratio (DER) terhadap harga saham sebagai berikut:

Tabel 8: Hasil Pengaruh Langsung

\begin{tabular}{lrrr}
\hline \multicolumn{1}{c}{ Variabel } & T hitung & Signifikasi & Z-Value \\
\hline Earning Per Share (EPS) & $-2,357$ & 0,021 & \\
\cline { 1 - 3 } Price Earning Ratio (PER) & 2,048 & 0,045 & \multirow{2}{*}{0,781} \\
\hline Debt to Equity Ratio (DER) & 1.721 & 0,000 & \\
\hline
\end{tabular}

Sumber: Data sekunder diolah, 2016

Untuk mengetahui nilai $\mathrm{t}$ statistik tabel ditentukan tingkat signifikasi 5\% dengan derajat kebebasan yaitu $\mathrm{df}=(\mathrm{n}-\mathrm{k}-$ 1), dimana $\mathrm{n}=$ jumlah observasi dan $\mathrm{k}=$ jumlah variabel. Pada penelitian ini jumlah observasi sebanyak 70 dan jumlah variabel sebanyak 3 sehingga nilai $\mathrm{df}=$ 66 (70-3-1). Berdasarkan nilai df 66 maka didapatkan nilai $\mathrm{t}$ tabel sebesar 1,668 atau -1,668. Uji parsial masingmasing variabel dapat dijelaskan sebagai berikut:

\section{Pengaruh Earning Per Share (EPS) Terhadap Harga Saham}

Berdasarkan hasil olah data menunjukkan t hitung Earning Per Share (EPS) sebesar -2,357 dan t tabel sebesar -1,668 sehingga $t$ hitung lebih besar dari $t$ tabel $(-2,357>-1,668)$ artinya terdapat pengaruh negatif Earning Per Share (EPS) terhadap harga saham. Nilai signifikasi sebesar
0,021 lebih kecil dari $0,05(0,021<$ $0,05)$ artinya signifikan.

Dapat disimpulkan bahwa terdapat pengaruh negatif signifikan Earning Per Share (EPS) terhadap harga saham artinya semakin rendah Earning Per Share (EPS) maka semakin tinggi harga saham.

Pertumbuhan profitabilitas perusahaan juga merupakan indikator yang sangat penting diperhatikan untuk mengetahui sejauh mana investasi yang akan dilakukan oleh investor di suatu perusahaan mampu memberikan return yang sesuai dengan tingkat yang disyaratkan investor.

Earning Per Share (EPS) merupakan kemampuan dari modal yang diinvestasikan dalam keseluruhan aktiva untuk menghasilkan keuntungan bagi semua investor. Tinggi rendahnya Earning 
Per Share (EPS) perusahaan selain tergantung pada keputusan perusahaan, bentuk investasi atau aktiva (keputusan investasi) juga tergantung peda tingkat efisiensi penggunaan aktiva perusahaan. Semakin besar Earning Per Share (EPS) menunjukkan kinerja semakin baik, karena tingkat kembalian (return) semakin besar. Pengaruh negatif Earning Per Share (EPS) menunjukkan bahwa pengelolaan perusahaan kurang efisien sehingga investor menilai kinerja perusahaan kurang baik dan menyebabkan harga saham menjadi turun. Pengelolaan perusahaan yang kurang efisien disini bisa disebabkan karena beberapa faktor diantaranya suatu lembaga keuangan menghasilkan laba bersih yang tinggi tetapi lembaga keuangan tersebut juga harus mengeluarkan biaya-biaya yang lebih tinggi untuk pemeliharaan aktiva tetap dan biaya depresiasi alat-alat dan gedung, selain itu dapat disebabkan oleh suatu lembaga keuangan menghasilkan laba bersih yang rendah tetapi lembaga keuangan tersebut harus mengeluarkan biaya-biaya pemeliharaan aktiva tetap dan biaya depresiasi alat-alat dan gedung yang tinggi, jadi bisa dikatakan pengelolaan lembaga keuangan disini kurang efisien.

Signalling theory menjelaskan mengapa perusahaan mempunyai dorongan untuk memberikan informasi laporan keuangan pada pihak eksternal. Dorongan perusahaan untuk memberikan informasi karena terdapat asimetri informasi antara perusahaan dan pihak luar karena perusahaan mengetahui lebih banyak mengenai perusahaan dan prospek yang akan datang daripada pihak luar (investor dan kreditur). Dengan adanya pengaruh negative menunjukkan sinyal buruk bagi investor.

Hal ini sesuai dengan penelitian yang dilakukan oleh Setiadi, dkk (2014) yang menyatakan bahwa profitabilitas yang diukur dengan Return on Equity berpengaruh negatif terhadap harga saham. Return on Equity negatif menunjukan bahwa dari total aktiva yang digunakan perusahaan mengalami kerugian. Emiten akan berusaha meningkatkan keuntungannya karena mereka menyadari betul betapa pentingnya keuntungan bagi masa depan perusahaan.

\section{Pengaruh Price Earning Ratio (PER) Terhadap Harga Saham}

Berdasarkan hasil olah data menunjukkan t hitung Price Earning Ratio (PER) sebesar 2,048 dan t tabel sebesar 1,668 sehingga t hitung lebih besar dari $t$ tabel $(2,048>1,668)$ artinya terdapat pengaruh positif Price Earning Ratio (PER) terhadap harga saham. Nilai signifikasi sebesar 0,045 lebih kecil dari $0,05(0,045<0,05)$ artinya signifikan.

Dapat disimpulkan bahwa terdapat pengaruh positif signifikan Price Earning Ratio (PER) terhadap harga saham artinya semakin tinggi Price Earning Ratio (PER) maka harga saham semakin meningkat.

Price Earning Ratio menunjukkan perbandingan harga saham yang dibeli dengan earning yang akan diperoleh dikemudian hari sehingga hal tersebut menunjukkan bahwa investor yakin terhadap besarnya earning yang diberikan perusahaan, yang nantinya akan dibagikan kepada pemegang saham dalam bentuk dividen di masa datang. Dapat dikatakan bahwa investor di Indonesia yang memilih perusahaan makanan dan minuman lebih berorientasi untuk mempertimbangkan Price Earning 
Ratio untuk menentukan keuntungan dalam berinvestasi. Harga saham dan Price Earning Ratio memiliki hubungan yang kuat, karena Price Earning Ratio itu menunjukkan pertumbuhan laba dari perusahaan, dan investor akan tertarik terhadap pertumbuhan laba tersebut sehingga pada akhirnya akan memberikan efek terhadap pergerakan harga saham. Dapat disimpulkan bahwa Price Earning Ratio memiliki pengaruh signifikan yang berbanding terbalik terhadap harga saham, di mana semakin kecil Price Earning Ratio maka akan meningkatkan harga saham karena akan menarik minat investor untuk membeli saham.

Perusahaan memberikan sinyal positif bagi investor untuk memberi petunjuk bagi investor tentang bagaimana manajemen memandang prospek perusahaan. Sinyal ini berupa informasi mengenai apa yang sudah dilakukan oleh manajemen untuk merealisasikan keinginan pemilik.

Hal ini sesuai dengan penelitian yang dilakukan oleh Hamka (2012) yang menyatakan bahwa yang menyimpulkan bahwa variabel Price Earning Ratio berpengaruh signifikan terhadap harga saham, sehingga peningkatan besarnya variabel Price Earning Ratio berpengaruh positif terhadap perubahan harga saham. Price Earning Ratio (PER) merupakan rasio untuk menghitung nilai intrinsik saham dengan membandingkan antara harga saham dengan earning (laba) perusahaan.

\section{Pengaruh Debt to Equity Ratio} (DER) Terhadap Harga Saham

Berdasarkan hasil olah data menunjukkan t hitung Debt to Equity Ratio (DER) sebesar 1.721 dan $\mathrm{t}$ tabel sebesar 1,668 sehingga t hitung lebih besar dari $\mathrm{t}$ tabel $(1.721>1,668)$ artinya terdapat pengaruh positif $D e b t$ to Equity Ratio (DER) terhadap harga saham. Nilai signifikasi sebesar 0,000 lebih kecil dari $0,05(0,000<0,05)$ artinya signifikan.

Dapat disimpulkan bahwa terdapat pengaruh positif signifikan Debt to Equity Ratio (DER) terhadap harga saham artinya semakin tinggi Debt to Equity Ratio (DER) maka semakin tinggi harga saham.

Debt to Equity Ratio (DER) berpengaruh positif terhadap harga saham terjadi karena strategi perusahaan dalam pendanaan memanfaatkan utang untuk mengurangi beban pajak. Penggunaan hutang dalam jumlah yang lebih besar akan mengurangi pajak dan menyebabkan makin banyak laba operasi (EBIT) perusahaan yang mengalir kepada investor. Selain itu, ketika aktivitas perusahaan semakin tinggi dapat disinyalir bahwa produknya mampu menembus pasar yang ditargetkan dan akan mendatangkan tingkat keuntungan yang semakin tinggi. Hal ini terjadi karena perusahaan makanan dan minuman merupakan produk makanan yang memang dibutuhkan oleh masyarakat guna memenuhi kebutuhan sehari-hari, sehingga disinyalir target penjualan dapat tercapai. Jadi, meskipun Debt to Equity Ratio (DER) tinggi, tetapi laba yang mengalir kepada investor tetap tinggi yang menyebabkan harga saham juga tinggi.

Hal ini sesuai dengan pendapat Ircham, dkk (2014) yang menyatakan bahwa Debt to Equity Ratio (DER) berpengaruh positif terhadap harga saham. Nilai yang tinggi pada DER ini menunjukkan sebagian besar kegiatan operasional perusahaan dibiayai oleh hutang. Hal ini menyebabkan risiko yang tinggi, karena keuntungan yang didapat perusahaan akan 
diprioritaskan untuk membayar beban bunga dan pokok hutang. Risiko yang tinggi menyebabkan harga saham turun karena saham kurang diminati investor dan permintaan saham pun menurun.

\section{Pengaruh Tidak Langsung \\ Pengaruh Earning Per Share (EPS) Terhadap Harga Saham Melalui Debt to Equity Ratio (DER)}

Untuk menghitung pengaruh tidak langsung Earning Per Share (EPS) terhadap harga saham melalui Debt to Equity Ratio (DER) dengan taraf signifikasi sebagai berikut:

Pengaruh $\mathrm{X}_{1}$ terhadap $\mathrm{Y}=0,015$

Pengaruh $Y$ terhadap $Z=0,000$

Pengaruh $\mathrm{X}_{1}$ terhadap $\mathrm{Z}$ melalui $\mathrm{Y}$

Hasil perhitungan pengaruh tidak langsung Earning Per Share (EPS) terhadap harga saham melalui Debt to Equity Ratio (DER) sebesar 0,000 yang berarti kurang dari 0,05 artinya terdapat pengaruh tidak langsung Earning $\mathrm{Per}$ Share (EPS) terhadap harga saham melalui Debt to Equity Ratio (DER).

Pertumbuhan profitabilitas perusahaan juga merupakan indikator yang sangat penting diperhatikan untuk mengetahui sejauh mana investasi yang akan dilakukan oleh investor di suatu perusahaan mampu memberikan return yang sesuai dengan tingkat yang disyaratkan investor. EPS yang tinggi menandakan perusahaan tersebut mampu memberikan tingkat kesejahteraan yang lebih baik kepada pemegang saham, sedangkan EPS yang rendah menandakan bahwa perusahaan gagal memberikan manfaat sebagaimana diharapkan oleh pemegang saham.

Debt to equity ratio menggambarkan perbandingan antara total hutang dengan total ekuitas perusahaan yang digunakan sebagai sumber pendanaan usaha. Debt to equity ratio mengungkapkan bagaimana penggunaan pendanaan perusahaan dari struktur modal yang dimiliki oleh perusahaan yang berasal dari utang jangka panjang dan modal yang berasal dari ekuitas. Semakin besar DER menandakan struktur permodalan usaha lebih banyak memanfaatkan utang-utang relatif terhadap ekuitas dan mencerminkan risiko perusahaan yang relatif tinggi.

Menurut Hamka (2012) Earning per Share berpengaruh positif terhadap harga saham. Earning per Share dapat dinilai kemampuan perusahaan dalam membagikan labanya kepada para pemegang saham. Semakin tinggi laba perusahaan yang diberikan kepada para pemegang saham akan menambah daya tarik investor dan mendorong untuk memiliki saham $\overline{\bar{m}}$ tersebut, sehingga menyebabkan meningkatnya harga saham. Keterangan tersebut menunjukkan bahwa Earning per Share mempunyai pengaruh positif terhadap harga saham perusahaan. Menurut Irkham, dkk (2014) DER berpengaruh signifikan positif terhadap harga saham, artinya semakin tinggi nilai DER maka akan semakin tinggi pula harga saham. Debt to equity ratio mengungkapkan bagaimana penggunaan pendanaan perusahaan dari struktur modal yang dimiliki oleh perusahaan yang berasal dari utang jangka panjang dan modal yang berasal dari ekuitas. DER berpengaruh positif terhadap harga saham menunjukkan bahwa investor memperhatikan berapa besar modal yang dibiayai oleh mereka kepada perusahaan untuk menghasilkan laba bersih untuk mereka. Semakin besar DER menandakan struktur permodalan usaha lebih banyak memanfaatkan dana yang disediakan oleh kreditur untuk menghasilkan laba.

Berdasarkan perhitungan yang telah dilakukan melalui uji sobel test dapat diketahui bahwa variabel Debt to Equity Ratio (DER) merupakan 
intervening Earning Per Share (EPS) terhadap harga saham.

Pengaruh Price Earning Ratio (PER) Terhadap Harga Saham Melalui Debt to Equity Ratio (DER)

Untuk menghitung pengaruh tidak langsung Price Earning Ratio (PER) terhadap harga saham melalui Debt to Equity Ratio (DER) dengan taraf signifikasi sebagai berikut:

Pengaruh $\mathrm{X}_{1}$ terhadap $\mathrm{Y}=0,187$

Pengaruh $Y$ terhadap $Z=0,000$

Pengaruh $\mathrm{X}_{1}$ terhadap $\mathrm{Z}$ melalui $\mathrm{Y}$

Hasil perhitungan pengaruh tidak langsung Price Earning Ratio (PER) terhadap harga saham melalui Debt to Equity Ratio (DER (DER) sebesar 0,000 yang berarti kurang dari 0,05 artinya terdapat pengaruh tidak langsung Price Earning Ratio (PER) terhadap harga saham melalui Debt to Equity Ratio (DER).

Investasi adalah menyimpan uang atau mengeluarkan uang dengan harapan suatu saat dapat keuntungan finansial. Setiap penggunaan investasi dimaksudkan untuk meningkatkan kemakmuran pemodal. Jika dikatakan saham mempunyai P/E Ratio 10 kali, berarti harga saham tersebut 10 kali lipat terhadap EPS-nya (pendapatan bersih per lembar saham). Saham yang mempunyai P/E Ratio semakin kecil akan semakin bagus, yang berarti saham tersebut semakin murah. Debt to equity ratio menggambarkan perbandingan antara total hutang dengan total ekuitas perusahaan yang digunakan sebagai sumber pendanaan usaha. Debt to equity ratio mengungkapkan bagaimana penggunaan pendanaan perusahaan dari struktur modal yang dimiliki oleh perusahaan yang berasal dari utang jangka panjang dan modal yang berasal dari ekuitas. Semakin besar DER menandakan struktur permodalan usaha lebih banyak memanfaatkan utang-utang relatif terhadap ekuitas dan mencerminkan risiko perusahaan yang relatif tinggi.

Menurut Dewi dan Sudiartha (2013) PER terhadap harga saham berpengaruh negatif terhadap harga saham. Ini berarti dikarenakan bahwa investor cenderung berinvestasi pada perusahaan yang memiliki nilai PER rendah. Bahwa pada periode ini, investor tidak melihat harga saham sebagai acuan dalam berinvestasi, tetapi investor menggunakan tingkat laba per lembar saham oleh yang o,000 dikeluarkan oleh perusahaan. Dalam hal ini nilai PER yang rendah dapat menunjukkan bahwa tingkat laba per lembar saham yang dihasilkan oleh suatu perusahaan adalah rendah yang jika dibandingkan pada harga saham tersebut. Menurut Irkham, dkk (2014) DER berpengaruh signifikan positif terhadap harga saham, artinya semakin tinggi nilai DER maka akan semakin tinggi pula harga saham. Debt to equity ratio mengungkapkan bagaimana penggunaan pendanaan perusahaan dari struktur modal yang dimiliki oleh perusahaan yang berasal dari utang jangka panjang dan modal yang berasal dari ekuitas. DER berpengaruh positif terhadap harga saham menunjukkan bahwa investor memperhatikan berapa besar modal yang dibiayai oleh mereka kepada perusahaan untuk menghasilkan laba bersih untuk mereka. Semakin besar DER menandakan struktur permodalan usaha lebih banyak memanfaatkan dana yang disediakan oleh kreditur untuk menghasilkan laba.

Berdasarkan hasil analisis sobel test for excel yang telah dilakukan melalui uji sobel test dapat diketahui bahwa variabel Debt to Equity Ratio (DER) bukan merupakan intervening Price Earning Ratio (PER) terhadap harga saham.

\section{E. PENUTUP}

Berdasarkan dari hasil penelitian diatas dapat diambil beberapa 
kesimpulan. Pertama, Terdapat pengaruh negatif signifikan Earning Per Share (EPS) terhadap Debt to Equity Ratio (DER) dan terhadap harga saham. Kedua, tidak terdapat pengaruh Price Earning Ratio (PER) terhadap Debt to Equity Ratio (DER). Ketiga, terdapat pengaruh positif signifikan Price Earning Ratio (PER) dan Debt to Equity Ratio (DER) terhadap harga saham, terhadap harga saham. Selain itu, juga terdapat pengaruh tidak langsung Earning $\mathrm{Per}$ Share (EPS) terhadap harga saham melalui Debt to Equity Ratio (DER) serta Price Earning Ratio (PER) terhadap harga saham melalui Debt to Equity Ratio (DER).

Dari simpulan diatas, disarankan khususnya bagi perusahaan yang diteliti untuk lebih memperhatikan net income yang digunakan untuk menghitung Earnings Per Share. Hal ini disebutkan demikian karena menurut hasil penelitian, nilai Earnings Per Share cukup tinggi dalam mempengaruhi harga saham daripada variabel Net Profit Margin dan Return on Equity. Tinggi rendahnya harga saham itu sendiri dapat mempengaruhi keputusan para investor atau calon investor untuk membeli saham emiten tersebut. Sedangkan bagi peneliti selanjutnya, disarankan untuk mengambil variabel dan sampel penelitian yang berbeda dari yang diambil penulis sehingga akan memberikan hasil yang lebih berguna bagi perkembangan perekonomian di Indonesia, khususnya bagi perusahaan-perusahaan yang listed di BEI.

\section{DAFTAR PUSTAKA}

Adi, Angantyo, Dkk. 2012. Pengaruh Return On Equity, Debt To Equity Ratio, Earning Per Share Dan Book Value Per Share Terhadap Harga Saham (Studi Pada Perusahaan Consumer Goods
Industry Yang Terdaftar Di Bei Periode Tahun 2008-2011). Malang: Universitas Brawijaya

Arikunto, S. 2010. Prosedur penelitian : Suatu Pendeka0tan Praktik. Jakarta: Rineka Cip

Baridwan, Zaki. 2012. Intermediate accounting. BPFE: Yogyakarta

Brigham, Eugene F. dan Joel F. Houston. 2012. Dasar-dasar Manajemen Keuangan. Jakarta: Salemba Empat Budiman, Aditya. 2015. Ekonomi Memburuk, Laba Perusahaan Makanan Ini Turun 37,2 Persen. Diunggah pada tanggal Sabtu, 09 Mei $2015 \quad 04: 40$ WIB. ttps://m.tempo.co/read/news $/ 2015 / 0$ 5/09/090664782/ekonomimemburuk-laba-perusahaanmakanan-ini-turun-37-2-persen

Dahlan, Siamat. 2011. Manajemen Lembaga Keuangan, Kebijakan Moneter dan Perbankan. Jakarta: Universitas Indonesia

Darmadji \& Fakhruddin. 2012. Pasar Modal di Indonesia. Jakarta: Salemba Empat

Dewi, Gusti Ayu Ketut Chandni Dan Sudiartha, Gede Merta. 2013. Pengaruh Price Earning Ratio, Dividend Payout Ratio, Ireturn On Assets, Tingkat Suku Bunga Sbi, Serta Kurs Dollar As Terhadap Harga Saham. Bal:i Universitas Udayana

Djauharotun.2005. Pengaruh Earning Per Share (Eps) Dan Pertumbuhan Penjualan Terhadap Harga Saham Pada Perusahaan Tekstil Dan Garmen Di BEJ. Semarang: Universitas Diponegoro

Fahmi, Irham. 2012. Analisis Laporan Keuangan. Bandung: Alfabeta

Ghozali, Imam. 2013. Aplikasi Analisis Multivariat dengan Program IBM SPSS 21. Semarang: Penerbit Universitas Diponegoro 
Hamka, Arman M.S. 2012. Pengaruh Variabel Earning per Share (EPS), Price Earning Ratio (PER), dan Return on Equity (ROE) Terhadap Harga Saham. (Studi Pada Perusahaan Pertambangan yang Terdaftar di Bursa Efek Indonesia). Malang: Universitas Brawijaya

Hery. 2011. Teori Akuntansi, Pelaporan Keuangan dan Standar Akuntansi \& Kerangka Kerja Konseptual. Jakarta: FASB

Husnan, Suad. 2012. Teori Portofolio dan Analisis Sekurita. Yogyakarta: UPP STIM YKPN

Ircham, Muhammad, Dkk. 2014. Pengaruh Struktur Modal Dan Profitabilitas Terhadap Harga Saham (Studi Pada Perusahaan Makanan Dan Minuman Yang Terdaftar Di Bursa Efek Indonesia Tahun 2009-2012). Malang: Universitas Brawijaya Jurnal Administrasi Bisnis (JAB) Vol. 11 No. 1 Juni 2014

Jogiyanto, Hartono. 2013. Teori Portofolio dan Analisis Investasi. Yogyakarta: BPFE Yogyakarta

Kamaludin dan Indriani, Rini. 2012. Manajemen Keuangan Konsep Dasar dan Penerapannya. Bandung: Penerbit CV. Mandar..

Kasmir. 2012. Analisis Laporan Keuangan. Jakarta: PT.Raja Grafindo Persada

Kertonegoro, Sentanoe. 2009. Analisis dan Manajemen Investsi. Jakarta: Widya Press

Kismono, Gugup. 2011. Pengantar Bisnis. Yogyakarta: Penerbit BPFE

Menike and Prabath. 2014. The Impact of Accounting Variables on Stock Price: Evidence from the Colombo Stock Exchange. Sri Lanka: Dongbei University of Finance and Economics International Journal of Business and Management; Vol. 9, No. 5; 2014
Munawir, S. 2012. Analisis Informasi Keuangan. Yogyakarta: Liberty.

Pertiwi, Ni Wayan Aditya Putri dan Artini, Luh Gede Sri. 2012. Pengaruh Risiko Bisnis, Profitabilitas, Dan Keputusan Investasi Terhadap Struktur Modal. Bali: Unviersitas Udayana

Riyanto, Bambang. 2010. Dasar-Dasar Pembelanjaan Perusahaan. Yogyakarta: Penerbit BPFE

Rusdin. 2010. Pasar Modal. Bandung: Alfabeta

Sarasati, Gusti. 2013. Analisis Pengaruh Profitabilitas, Price Earning Ratio, Struktur Aktiva, Operating Leverage, Dan Pertumbuhan Pernjualan Terhadap Struktur Modal (Studi Kasus Pada Perusahaan Real Estate Dan Property Yang Terdaftar Di Bei Periode 2008-2011). Semarang: Universitas Diponegoro

Sawir, Agnes. 2012. Analisis Kinerja Keuangan dan Perencanaan Keuangan Perusahaan. Jakarta: PT. Gramedia Pustaka Utama.

Sugiyono. 2010. Metode Penelitian Kuantitatif Kualitatif dan $R \& D$. Bandung: Alfabeta

Sunariyah. 2011. Pengantar pengetahuan pasar modal. Yogyakarta: Sekolah Tinggi Ilmu Manajemen YKPN.

Tandelilin, Eduardus. 2010. Analisis Investasi dan Manajemen Portofolio. Yogyakarta: BPFE.

Widoatmodjo, Sawidji. 2012. Cara Cepat Memulai Investasi Saham Panduan Bagi Pemula. Jakarta: PT Elex Media Komputindo 